\title{
Evaluation of biofilm formation by bacterial strains isolated from milking equipment and milk samples from cows with mastitis
}

\section{Avaliação da formação de biofilme por cepas bacterianas isoladas de equipamentos de ordenha e do leite de vacas com mastite}

\author{
Laura Gonçalves da Silva Chagas ${ }^{*}$; Poliana de Castro Melo²; \\ Silvia Cassimiro Brasão ${ }^{1}$; Gabriela Bim Ramos Silvestre ${ }^{1}$; \\ Ednaldo Carvalho Guimarães ${ }^{3}$; Anna Monteiro Correia Lima ${ }^{3}$
}

\begin{abstract}
The presence of biofilm-forming bacteria from the mammary gland of dairy cows adhered to equipment in the milking environment represents one of the major causes of bacterial resistance during mastitis treatment. The aim of this study was to identify strains of Staphylococcus aureus, Staphylococcus epidermidis and Escherichia coli in milk samples from cows with mastitis, as well as in the expansion tank and milking set liners. We aimed to quantify the extracellular proteins and polysaccharides in the biofilm produced by each strain. A total of 294 samples were collected from a dairy farm in the municipality of Uberlândia, Minas Gerais. To identify the $S$. aureus, S. epidermidis and E. coli isolates responsible for biofilm production, we tested the phenotype using the Congo red agar (CRA) and microplate adhesion tests. Protein quantification was performed with a Bicinchoninic Acid Protein Assay Kit (BCA kit), and polysaccharides were quantified by the phenol sulfuric acid method. We identified eight strains of $S$. aureus, one strain of $S$. epidermidis and 11 strains of E. coli responsible for biofilm production, all of which showed a higher concentration of polysaccharides than proteins in the matrix. Escherichia coli was considered the most prevalent bacterium among the samples, and $S$. aureus was determined to be the largest biofilm producer. The results of the CRA and microplate adhesion tests were similar in regard to identification of the biofilm-producing strains according to their phenotype and matrix composition. The classification of $S$. aureus strains as major biofilm producers is of great concern for producers, as such bacteria are considered one of the predominant contagious etiological agents that cause bovine mastitis. In addition, our observation that E. coli and S. epidermidis can produce biofilms highlights the need to reassess prophylactic measures to avoid the adhesion of biofilm-producing bacteria.
\end{abstract}

Key words: Staphylococcus aureus. Staphylococcus epidermidis. Escherichia coli. Dairy cows.

\section{Resumo}

A presença de bactérias formadoras de biofilme microbiano, na glândula mamária de vacas leiteiras e aderidas aos equipamentos e utensílios do ambiente de ordenha, constitui uma das causas de resistência bacteriana no tratamento de mastite em vacas leiteiras. O estudo teve como finalidade identificar cepas produtoras de biofilme de Staphylococcus aureus, Staphylococcus epidermidis e Escherichia coli, em amostras de leite de animais com mastite, tanque de expansão e teteiras do conjunto de ordenha. Visouse quantificar as proteínas extracelulares e polissacarídeos das estirpes. No total, foram colhidas 294

\footnotetext{
${ }^{1}$ Mestres, Universidade Federal de Uberlândia, UFU, Uberlândia, MG, Brasil. E-mail: lauravetufu@gmail.com; silvia_cb_vet@ yahoo.com.br; gabivetufu@yahoo.com.br

2 Profa, Universidade Estadual de Santa Cruz, UESC, Ilhéus, BA, Brasil. E-mail: policame@yahoo.com.br

3 Profs., Uberlândia, MG, Brasil. E-mail: ecg@ufu.br; annalimaufu@yahoo.com.br

* Author for correspondence
} 
amostras, em uma propriedade no município de Uberlândia, Minas Gerais. Para identificar as estirpes de $S$. aureus, S. epidermidis e $E$. coli isoladas produtoras de biofilme, foram utilizados testes fenotípicos como cultivo em ágar Vermelho Congo (CRA) e teste de adesão em microplaca. A quantificação de proteínas foi realizada com o Kit BCA e de polissacarídeos pelo método do ácido fenol sulfúrico. Identificou-se oito cepas de $S$. aureus, uma de $S$. epidermidis e 11 cepas de E. coli produtoras de biofilme, todas compostas com maior concentração de polissacarídeo do que proteína na matriz. E. coli foi considerada a bactéria mais prevalente das amostras e $S$. aureus a maior produtora de biofilme. Os resultados do CRA e do teste de adesão em microplaca foram similares ao identificar as cepas produtoras de biofilme, conforme a expressão do fenótipo e quantificação da matriz. A classificação de estirpes de $S$. aureus, como maiores produtoras de biofilme, preocupa ainda mais os produtores, pois tais bactérias são consideradas um dos principais agentes etiológicos contagiosos causadores da mastite bovina. Além disso, a capacidade de E. coli e S. epidermidis produzirem biofilme torna indispensável a reavaliação das medidas profiláticas, com o intuito de evitar a adesão de bactérias produtoras de biofilme.

Palavras-chave: Staphylococcus aureus. Staphylococcus epidermidis. Escherichia coli. Bovino leiteiro.

\section{Introduction}

Bovine mastitis threatens both the income of cattle farmers and the reputation of the dairy sector, due to problems related to animal welfare, milk quality and public health (DE VLIEGHER et al., 2012). Although mastitis can be caused by numerous pathogens, bacteria of the Staphylococcus genus are recognized as the predominant etiological agents in cases of mastitis (DE VLIEGHER et al., 2012).

One of the causes of failure in the antimicrobial treatment of mastitis is the ability of biofilmproducing microorganisms to adhere to the surface of the breast tissue. The extracellular polymeric substance (EPS) present in the biofilm matrix protects the colonies from environmental stress (DONLAN, 2002; MELCHIOR et al., 2006; MELO et al., 2012).

Stepanovic et al. (2000) stated that the plaque adhesion test is one of the most frequently used methods for quantifying the biofilm production of Staphylococcus spp. It can also be used as an indicator of the pathogenicity of microorganisms. Strains that produce slime in the microplate assay potentially have the ability to adhere to mammary gland tissue. The presence of this mucopolysaccharide hinders the antibiotic treatment of mastitis, as well as reducing the innate immune response of the host (MARQUES et al., 2013).

It is imperative that quick and easy methods are available to investigate the presence of biofilmproducing bacteria so that more effective control and prophylaxis measures can be implemented (AGNOL et al., 2013; DARWISH; ASFOUR, 2013). The Congo red agar (CRA) culture and microplate adhesion tests are used to detect biofilm production by bacteria. The former is used to determine the phenotype based on the color of the colonies that grow, and the latter is used to quantify components of the biofilm matrix. Quantification of extracellular proteins and polysaccharides can be used to characterize the composition of the biofilm matrix, as the concentration of proteins and polysaccharides represent two factors that can be used to evaluate the virulence of each strain (SOUZA et al., 2009).

The purpose of this study was to identify the strains of Staphylococcus aureus, Staphylococcus epidermidis and Escherichia coli in milk samples from cows with mastitis, in the expansion tank and in the components of the milking set liners. We also aimed to verify biofilm-production by the strains identified, in addition to quantifying the extracellular proteins and polysaccharides of the biofilm produced by these strains.

\section{Materials and Methods}

We evaluated milk samples collected from 80 Girolando cows at a dairy farm in the city of Uberlândia, in the State of Minas Gerais, under 
the Federal University of Uberlândia. The average milk yield was around 1600 L per day, with milking performed mechanically in a closed-circuit system twice per day. We only selected milk samples from animals that were reactive to California Mastitis Test (CMT) and from those that showed signs of clinical mastitis, with all samples collected according to the aseptic standards proposed by Harmon et al. (1990).

A monthly harvest was carried out in the months of February, April and May of 2014, amounting to a total of 261 milk samples. After each monthly harvest, a milk sample was collected from the expansion tank following the second milking of the day, as recommended by Brito et al. (1998), totaling three samples. In order to collect samples from the liners, sterile swabs were rubbed in a circular motion around the final section of each liner across all milking sets, then the swabs were placed in Stuart medium as recommended by McDonald et al. (1993). We collected 10 monthly samples according to the number of insufflators used for milking, totaling 30 samples.

The samples were preserved in a box made of isothermal material containing recyclable ice, and transported to the Laboratory of Infectious Diseases at the Federal University of Uberlândia, Minas Gerais. Staphylococcus aureus strains were selected because of their contagious nature and recognition as being the major etiological agent in several cases of bovine mastitis. We also evaluated the presence of E. coli strains commonly found in the environment, the presence of which represents an indicator of environmental contamination (LANGONI et al., 2015). Considering increased recognition of the role of coagulase-negative staphylococci in biofilm production and pathogenicity, S. epidermidis was also chosen as it represents the most important and frequently reported bacteria in the literature (OLIVEIRA et al., 2007).

For the isolation and identification of Staphylococcus spp., we firstly spread $10 \mu 1$ of the milk samples onto the surface of Baird
Parker (Himedia) agar selective medium (SILVA et al., 1997), then left the plates to incubate at $37^{\circ} \mathrm{C}$ between 24 and $48 \mathrm{~h}$. Colonies found to be positive for catalase, and the Gram-positive cocci tests were further submitted to a tube coagulase test to differentiate between coagulase-positive staphylococci (ECP) and coagulase-negative staphylococci (ECN) (KONEMAN, 2001).

Staphylococcus aureus was identified by acetoin production and fermentation of maltose and trehalose (KONEMAN, 2001). Staphylococcus epidermidis was identified by a simplified method described by Koneman (2001) based on their use of sucrose and trehalose, growth in anaerobic thioglycolate medium and resistance to polymyxin $\mathrm{B}$.

In order to isolate and identify E. coli, we spread $10 \mu \mathrm{l}$ of the milk samples onto the surface of selective eosin methylene blue (EMB; Merck) medium, then incubated the samples at $35 \pm 2{ }^{\circ} \mathrm{C}$ for 18 to $24 \mathrm{~h}$ in a microaerophilic environment in anaerobic jars. From the colonies that grew, those that presented a large size and a black-blue color with metallic green reflection were submitted to Gram staining to evaluate the morphology of the Gram-negative bacteria. The identified colonies were seeded by puncture into a tube containing Rugai medium (Newprov), then incubated at $35^{\circ} \mathrm{C}$ for 18 to $24 \mathrm{~h}$, followed by biochemical screening, differentiation of enterobacteria and identification of E. coli (KONEMAN, 2001).

Biofilm production was determined by culturing CRA, consisting of $0.8 \mathrm{~g}$ of Congo red dye (Vetec) and $50 \mathrm{~g}$ of sucrose (Himedia) for every $1 \mathrm{~L}$ of brain-heart infusion agar (Himedia) (FREEMAN et al., 1989). The CRA plates were inoculated and incubated for $48 \mathrm{~h}$ at room temperature, followed by incubation for $48 \mathrm{~h}$ at $37^{\circ} \mathrm{C}$. The black, rough colonies were able to be differentiated from nonbiofilm-producing strains, which were smooth, red colonies.

The in vitro biofilm production capacity was determined according to the method described by 
Cucarella et al. (2004) with minor modifications, as described below. The bacteria were cultured individually overnight in tryptic soy broth (TSB) (Kasvi) at $37^{\circ} \mathrm{C}$. Suspended cells were diluted 1:200 in TSB containing $0.25 \%$ glucose (Synth), inoculated into sterile, flat bottom 96-well polystyrene microplates, then incubated for $24 \mathrm{~h}$ at $37^{\circ} \mathrm{C}$ with shaking, with medium renewal after $12 \mathrm{~h}$.

The wells were washed three times with 200 $\mu \mathrm{l}$ of sterile saline solution $(0.85 \% \mathrm{NaCl})$, then incubated for about $30 \mathrm{~min}$ in an oven at $60^{\circ} \mathrm{C}$ until the plate had dried. A $200-\mu 1$ aliquot of $1 \%$ crystal violet was added to each well and left for $5 \mathrm{~min}$. The plates were washed with distilled water and dried, then $200 \mu \mathrm{l}$ of $33 \%$ acetic acid (Isofar) was added to each well and the plates were read at $570 \mathrm{~nm}$ using a spectrophotometer (Multiskan GO; ThermoScientific,). Non-inoculated wells containing TSB and glucose were used as the blank. Strains with an absorbance greater than 0.1 were considered to be biofilm-producing bacteria. Each strain was tested for biofilm production in triplicate, and the experiment was repeated twice. The intensity of slime production was classified as either strong (absorbance greater than 0.3), moderate (absorbance between 0.2 and 0.3 ) or weak (absorbance between 0.1 and 0.2 ) depending on the absorbance (DEMO, 1996).

For protein and polysaccharide quantification, the biofilm-producing strains were diluted at 1:200 with TSB and $0.25 \%$ glucose, then incubated in 96well microplates for $24 \mathrm{~h}$ at $37^{\circ} \mathrm{C}$ with shaking, with medium renewal after $12 \mathrm{~h}$. The material was then scraped with phosphate buffered saline (PBS) after removal of the culture medium to perform the tests described below (GOMES, 2010).

For the quantification of extracellular biofilm proteins, we added $25 \mu \mathrm{l}$ of the sample and $200 \mu \mathrm{l}$ of the reagent mixture from the BCA kit (Sigma) to the microplate, which was homogenized for $30 \mathrm{~s}$ then incubated for $30 \mathrm{~min}$ at room temperature. Plates were read at $562 \mathrm{~nm}$ using the spectrophotometer
(ThermoScientific), with phosphate buffer used as the blank (AZEREDO et al., 1999).

For quantification of the polysaccharides, we placed $0.5 \mathrm{ml}$ of the sample into a tube with 0.5 $\mathrm{ml}$ of phenol $(50 \mathrm{~g} / \mathrm{L}$; Dynamic), then $2.5 \mathrm{ml}$ of sulfuric acid (95-97\%; Isofar) was added. The solution was homogenized in a vortex and left to react for $15 \mathrm{~min}$ at room temperature. The solution was measured at $490 \mathrm{~nm}$ in the spectrophotometer (ThermoScientific), with phosphate buffer used as the blank (DUBOIS et al., 1956).

This project was approved by the Ethics Committee on the Use of Animals (CEUA) of the Federal University of Uberlândia (UFU) under protocol number 076/14.

Analyses of the prevalence and production of biofilms by $S$. aureus, $S$. epidermidis and E. coli strains were performed using the binomial test for two proportions with a significance level of 5\%. All analyses were performed using BioEstat software (AYRES et al., 2007). The test of averages (t-test) was used to compare the protein and polysaccharide content of biofilms (TRIOLA, 1999).

\section{Results and Discussion}

Among the 294 analyzed samples, we identified 85 samples (28.91\%) of Staphylococcus spp., namely $11(12.94 \%)$ coagulase-positive and 74 $(87.06 \%)$ coagulase-negative. Of the coagulasepositive staphylococci samples, eight $(72.72 \%)$ were $S$. aureus and three (27.27\%) were S. schleiferi subspecies coagulans. Of the coagulase-negative staphylococci, three $(4.05 \%)$ were $S$. epidermidis, $17(22.97 \%)$ S. simulans and 54 (72.98\%) were other species of ECN. No Staphylococcus spp. were observed in either the expansion tank samples or liner swabs. Twenty-two samples of $E$. coli were isolated, 17 of which were from cows with mastitis and five from the swabs. Six milk samples and five liner swab samples were identified as biofilmproducers. 
Martins et al. (2010) examined 432 milk samples, of which 304 showed positive results in the CMT test. According to the microbiological analysis, 80 (26.31\%) were Corynebacterium spp., 71 (23.35\%) were $S$. aureus, 18 (5.90\%) were $S$. intermedius, two $(0.65 \%)$ were ECN and one $(0.32 \%)$ was $E$. coli. These data differ from the results of the present study, in which comparison between the identified strains of $S$. aureus, $S$. epidermidis and E. coli by the binomial test (AYRES et al., 2007) showed that $E$. coli was significantly more prevalent than Staphylococcus spp.

The expansion tank and swabs were investigated, and among the investigated bacteria, five E. coli strains were isolated from the liners. The presence of biofilm-producing E. coli in the dairy farm indicates a lack of hygiene in regard to the animals and equipment. Sanitizing agents may have been used for an insufficient amount of time or in an inadequate quantity, allowing the establishment of $E$. coli strains related to fecal contamination. The isolation of biofilm-producing strains on the milking equipment and in the environment suggests a high risk that the raw milk may be contaminated, which poses health risks to both humans and the animals themselves.

In their research on the adhesion of $E$. coli to surfaces, Pompermayera and Gaylarde (2000) reported that Gram-negative microorganisms can better adhere to surfaces and produce biofilms, due to the presence of flagella and the reduced time required for multiplication, which may explain its presence on the equipment.

A total of 20 biofilm-producing strains were identified, eight of which (40\%) were $S$. aureus, one (5\%) was $S$. epidermidis and 11 (55\%) were $E$. coli, all of which tested positive in both the CRA and adhesion tests. All strains were classified as strong biofilm producers, as their slime production intensity was higher than 0.3 absorbance (Table 1).
Among the identified bacteria, $S$. aureus showed the highest biofilm production level $(\mathrm{p}<0.05)$.

The presence of biofilm-forming bacteria in the mammary gland is considered one of the major challenges for treating cows with mastitis, because their presence in the mammary gland is difficult for the antibiotic, and consequently the active ingredient, to reach. The process of biofilm formation occurs over five steps: colonization, reversible adhesion, irreversible adhesion, matrix production and an increase in the number of cells, then detachment or exit of biofilm cells (COSTERTON et al., 1999). The release of cells from biofilms formed in the alveoli in the mammary gland allows for the contamination of other healthy mammary glands, as well as the contamination of equipment including insufflators and hoses. In light of this, it is essential that all equipment that comes into contact with the animals be properly cleaned and disinfected, particularly the milking machine sets.

Fabres-Klein et al. (2015) evaluated 54 strains of $S$. aureus isolated from cows with subclinical mastitis in farms in the state of Minas Gerais, of which $47(87.03 \%)$ were identified as biofilm producers in the adherence test. However, only $19(35.18 \%)$ were classified as slime producers according to the colony phenotype determined in the CRA test. Furthermore, Darwish and Asfour (2013) evaluated 108 samples of Staphylococcus spp., isolating 40 strains of $S$. aureus. Among the $27(67.50 \%)$ strains identified as biofilm producers, $21(52.50 \%)$ were classified as strong, $11(27.50 \%)$ as moderate and eight (20\%) as weak. These results differ from those obtained in the present study, in which all identified $S$. aureus strains expressed the phenotype in the CRA test, produced matrix in the crystal violet microplate test, and were classified as having a high adhesion capacity. These characteristics represent the greatest pathogenic potential of the identified strains, possibly due to acquired virulence and resistance factors. 
Table 1. Evaluation of biofilm formation in milk samples collected from dairy cows with mastitis and expansion tank at a dairy farm located in the municipality of Uberlândia, Minas Gerais, in February, April and May 2014.

\begin{tabular}{ccccccccc}
\hline & & & \multicolumn{3}{c}{ Biofilm test } & \\
\cline { 3 - 7 } Microorganisms & $\mathbf{N}$ & $\mathbf{\%}$ & \multicolumn{2}{c}{ Congo red } & $\begin{array}{c}\text { Test with crystal } \\
\text { violet microplates }\end{array}$ & Presence of biofilm \\
\cline { 3 - 7 } & & & $\mathbf{N}$ & $\mathbf{\%}$ & $\mathbf{N}$ & $\mathbf{\%}$ & Yes & No \\
\hline Staphylococcus aureus & 8 & 24.24 & 8 & 40 & 8 & 40 & $8 \mathrm{a}$ & 0 \\
Staphylococcus epidermidis & 3 & 9.10 & 1 & 5 & 1 & 5 & $1 \mathrm{~b}$ & 2 \\
Escherichia coli & 22 & 66.66 & 11 & 55 & 11 & 55 & $11 \mathrm{~b}$ & 11 \\
Total samples & 33 & 100 & 20 & 100 & 20 & 100 & 20 & 13 \\
\hline
\end{tabular}

Values followed by the same letter do not significantly differ from each other $(\mathrm{p}>0.05)$, as determined by the binomial test for two proportions.

Figure 1 shows the results of the quantification of polysaccharide and protein in all biofilm-producing samples. We observed that the EPS was mainly composed of polysaccharides, as most strains showed greater absorbance for polysaccharides than proteins. In addition, even though there was a statistically significant difference between the variables, there was no correlation between the content of proteins and polysaccharides.

Figure 1. Biochemical composition of the extracellular matrix of eight samples of Staphylococcus aureus (1 to 8), a sample of Staphylococcus epidermidis (9) and 11 samples of Escherichia coli (10 to 20), analyzed using the BCA kit and sulfuric phenol acid test.

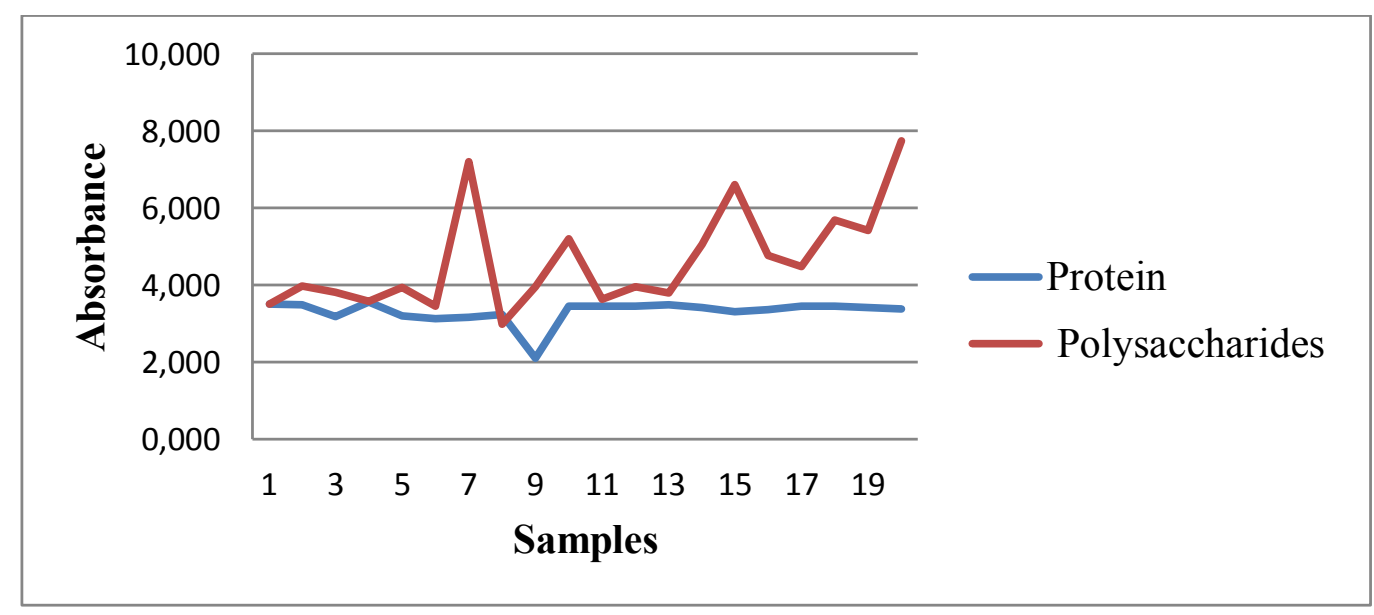

Melo et al. (2012) observed that crystal violet stained the exopolysaccharide matrix produced by bacteria in a microplate adhesion test, which enabled determination of the ability of strains to form a biofilm. The presence of proteins in the extracellular matrix is fundamental for the biofilm structure. Therefore, any mutations that occur within the genes responsible for the production of
EPS proteins alter the bacteria, causing it to behave as a biofilm producer (BRANDA et al., 2006). In this study, we observed that all biofilms had high concentrations of protein and polysaccharide.

Souza et al. (2009) extracted and quantified the proteins and polysaccharides in the biofilm produced by four strains of $S$. epidermidis. They observed that the amounts of protein and polysaccharide were 
proportional to the amount of biomass detected in the microplate assay, representing an indirect method for determining biomass. They found that the concentration of polysaccharides was higher than proteins for three of the tested strains. These data are similar to the results observed in the current study, in which most of the biofilm-producing strains had higher concentrations of polysaccharide than protein, except for two strains of $S$. aureus (Figure 1).

The method used to extract EPS may influence the yield and chemical composition of the extracellular polymers, leading to different degrees of cell lysis, and consequently, contamination of exopolymers with intracellular components (BURA et al., 1998). In addition, the amount of polymers may vary significantly depending on the strain (CHAIGNON et al., 2007). The biofilm matrix acts as a barrier that prevents the penetration of antibiotics and sanitizers, and high concentrations of proteins and polysaccharides act as a defense mechanism against external agents (SOUZA et al., 2009).

In this study, we used rapid techniques that cause minimal lysis of bacteria. We observed that $S$. aureus, S. epidermidis and E. coli presented different concentrations of polysaccharides dependent on the bacterium, although the protein concentration remained almost constant across the strains. These compounds play different roles in the formation and pathogenicity of biofilms of each strain. Our results suggest that the composition of the biofilm matrix varies according to the bacterial strain.

There is a need to define prophylactic strategies, such as the implementation of an effective cleaning plan and the regular use of proper disinfection processes, in order to prevent the formation of biofilms and obtain a higher quality product.

\section{Conclusions}

In this study, we observed that biofilm-producing strains of $S$. aureus, $S$. epidermidis and E. coli were present in milk samples from cows with mastitis, with $E$. coli also present in the insufflators; however, none of the strains were identified in the expansion tank. These results suggest that the presence of extracellular polymers in the biofilm is related to the total biomass, the composition of which was found to contain a higher concentration of polysaccharides than proteins.

\section{Acknowledgements}

The authors thank the Foundation for Research Support of the State of Minas Gerais (FAPEMIG) for funding this project and the Coordination for Improvement of Higher Education Personnel (CAPES) for granting the scholarship. We also thank the research group for their assistance in carrying out the experiment, as well as the farm for providing the samples for analysis.

\section{References}

AGNOL, A. M. D.; CAVALCANTE, M. B.; FRANÇA, C. A.; KREWER, C. C.; QUEIROS, A. A.; COSTA, M. M.; BRAGANÇA, J. F. M.; GIRARDINI, L. K. Caracterização fenotípica e molecular de isolados de Staphylococcus spp. obtidos de leite de ovelhas do Município de Chapecó-SC. Semina: Ciências Agrárias, Londrina, v. 34, n. 1, p. 311-322, 2013.

AYRES, M.; AYRES JUNIOR, M.; AYRES, D. L.; SANTOS, A. A. S. dos. BioEstat 5.0. Aplicações estatísticas nas áreas das ciências biológicas e médicas. Belém: Sociedade Civil Mamirauá; Brasília: Conselho Nacional de Desenvolvimento Científico e Tecnológico, 2007. 364 p.

AZEREDO, J. A.; LAZAROVA, V.; OLIVEIRA, R. Methods to extract the exopolymeric matrix from biofilms: a comparative study. Water Science and Technology, London, v. 39, n. 7, p. 243-250, 1999.

BRANDA, S. S.; CHU, F.; KEARNS, D. B.; LOSICK, R.; KOLTER, R. A major protein component of the Bacillus subtilis biofilm matrix. Molecular Microbiology, Oxford, v. 59, n. 4, p. 1229-1238, 2006. 
BRITO, M. A. V. P.; BRITO, J. R. F.; SOUZA, H. M.; VARGAS, O. L. Avaliação da sensibilidade da cultura de leite do tanque para isolamento de agentes contagiosos da mastite bovina. Pesquisa Veterinária Brasileira, Rio de Janeiro, v. 18, n. 1, p. 38-44, 1998.

BURA, R.; CHEUNG, M.; LIAO, B.; FINLAYSON, J.; LEE, B. C.; DROPPO, I. G.; LEPPARD, G. G.; LISS, S. N. Composition of extracellular polymeric substances in the activated sludge floc matrix. Water Science Technology, London, v. 37, n. 4-5, p. 325-333, 1998.

CHAIGNON, P.; SADOVSKAYA, I.; RAGUNAH, C. H.; RAMASUBBU, N.; KAPLAN, J. B.; JABBOURI, S. Susceptibility of staphylococcal biofilms to enzymatic treatments depends on their chemical composition. Applied Microbiology and Biotechnology, Berlin, v. 75, n. 1, p. 125-132, 2007.

COSTERTON, J. W.; STEWART, P. S.; GREENBERG, E. P. Bacterial biofilms: a common cause of persistent infections. Science, Lancaster, v. 284, n. 5418, p. 13181322, 1999.

CUCARELLA, C.; TORMO, M. A.; UBEDA, C.; TROTONDA, M. P.; MONZÓN, M.; PERIS, C.; AMORENA, B.; LASA, I.; PENADÉS, J. R. Role of biofilm associated protein bap in the pathogenesis of bovine Staphylococcus aureus. Infection and Immunity, Washington, v. 72, n. 4, p. 2177-2185, 2004.

DARWISH, S. F.; ASFOUR, H. A. E. Investigation of biofilm forming ability in Staphylococci causing bovine mastitis using phenotypic and genotypic assays. The Scientific World Journal, New York, v. 2013, p. 1-9, 2013. Available at: <http://dx.doi.org/10.1155/2013/378492>. Accessed at: 4 june 2015.

DE VLIEGHER, S.; FOX, L. K.; PIEPERS, S.; MCDOUGALL, S.; BARKEMA, H. W. Invited review: mastitis in dairy heifers: nature of the disease, potential impact, prevention, and control. Journal of Dairy Science, Lancaster, v. 95, n. 3, p. 1025-1040, 2012.

DEMO, M. Caracterizacion y studios de patogenicidad de cepas dela genero Staphylococcus asiladas de leches mastiticas, 1996. Tese (Doutorado en Microbiologia) - Universidad Nacional de Rio Cuarto, Rio Cuarto, Argentina.

DONLAN, R. M. Biofilms: microbial life on surfaces. Emerging Infectious Diseases, Atlanta, v. 8, n. 9, p. 881890, 2002.

DUBOIS, M.; GILLES, K. A.; HAMILTON, J. K.; REBERS, A.; SMITH, F. Colorimetric method for determination of sugars and related substances. Analytical Chemistry, Washington, v. 28, n. 3, p. 350-356, 1956.
FABRES-KLEIN, M. H.; SANTOS, M. J. C.; KLEIN, R. C.; SOUZA, G. N.; RIBON, A. O. B. An association between milk and slime increases biofilm production by bovine Staphylococcus aureus. BMC Veterinary Research, London, v. 11, n. 3, p. 1-8, 2015.

FREEMAN, D. J.; FALKINER, F. R.; KEANE, C. T. New method for detecting slime production by coagulase negative staphylococci. Journal of Clinical Pathology, Kuwait, v. 42, n. 8, p. 872-874, 1989.

GOMES, F. Novas estratégias terapêuticas contra biofilmes de Staphylococcus epidermidis. 2010. Tese (Doutorado em Engenharia Biomédica) - Universidade do Minho, Braga.

HARMON, R. J.; EBERHART, R. J.; JASPER, D. E.; LANGLOIS, B. E.; WILSON, R. A. Microbiological procedures for the diagnosis of bovine udder infection. Arlington: National Mastitis Council, 1990. 34 p.

LANGONI, H.; GUIMARÃES, F. F.; COSTA, E. O.; JOAQUIM, S. F.; MENOZZI, B. D. Celularidade do leite e unidades formadoras de colônias nas mastites causadas por Staphylococcus coagulase positiva e coagulase negativa. Pesquisa Veterinária Brasileira, Seropédica, v. 35, n. 6, p. 518-524, 2015.

KONEMAN, E. W. Diagnóstico microbiológico: texto e atlas colorido. 5. ed. Rio de Janeiro: Editora Médica e Científica Ltda, 2001. 1465 p.

MARQUES, V. F.; SOUZA, M. M. S.; MENDONÇA, E. C. L.; ALENCAR, T. A.; PRIBUL, B. R.; COELHO, S. M. O.; LASAGNO, M.; REINOSO, E. B. Análise fenotípica e genotípica da virulência de Staphylococcus spp. e de sua dispersão clonal como contribuição ao estudo da mastite bovina. Pesquisa Veterinária Brasileira, Rio de Janeiro, v. 33, n. 2, p. 161-170, 2013.

MARTINS, R. P.; SILVA, J. A. G.; NAKAZATO, L.; DUTRA, V.; ALMEIDA FILHO, E. S. Prevalência e etiologia infecciosa da mastite bovina na microrregião de Cuiabá, MT. Ciência Animal Brasileira, Goiânia, v. 11, n. 1, p. 181-187, 2010.

MCDONALD, J. S.; KINSEL, M. L.; ADAMS, D. S.; DARLINGTON, R. L. Studying the effects of backflushing milking units. Veterinary Medicine, Chicago, v. 88, n. 4, p. 382-386, 1993.

MELCHIOR, M. B.; VAARKAMP, H.; FINKGREMMELS, J. Biofilms: a role in recurrent mastitis infections? Veterinary Journal, London, v. 171, n. 3, p. 398-407, 2006. 
MELO, P. C.; FERREIRA, L. M.; NADER-FILHO, A.; ZAFALON, L. F.; VICENTE, H. I. G. Análise fenotípica e molecular da produção de biofilmes por estirpes de Staphylococcus aureus isolados de casos de mastite subclínica bovina. Bioscience Journal, Uberlândia, v. 28, n. 1, p. 94-99, 2012.

OLIVEIRA, M.; NUNES, S. F.; CARNEIRO, C.; BEXIGA, R.; BERNARDO, F.; VILELA, C. L. Time course of biofilm formation by Staphylococcus aureus and Staphylococcus epidermidis mastitis isolates. Veterinary Microbiology, Amsterdam, v. 124, n. 1-2, p. 187-191, 2007.

POMPERMAYERA, D. M. C.; GAYLARDE, C. C. The influence of temperature on the adhesion of mixed cultures of Staphylococcus aureus and Escherichia coli to polypropylene. Food Microbiology, London, v. 17, n. 4, p. 361-365, 2000.
SILVA, N.; JUNQUEIRA, V. C. A.; SILVEIRA, N. F. A. Manual de métodos de análise microbiológica de alimentos. São Paulo: Livraria Varela, 1997. 295 p.

SOUZA, C.; TEIXEIRA, P.; OLIVEIRA, R. The role of extracellular polymers on Staphylococcus epidermidis biofilm biomass and metabolic activity. Journal of Basic Microbiology, Berlin, v. 49, n. 4, p. 363-370, 2009.

STEPANOVIC, S.; VUKOVIC, D.; DAKIC, I.; SAVIC, B.; VLAHOVIC, M. S. A modified microtiter-plate test for quantification of staphylococcal biofilm formation. Journal of Microbiology Methods, Amsterdam, v. 40, n. 2, p. 175-179, 2000.

TRIOLA, M. F. Introdução à estatística. 7. ed. Rio de Janeiro: LTC, 1999. $410 \mathrm{p}$. 
